

BOOK REVIEW

\title{
Review of Christian Wille's and Birte Nienaber's Edited Volume Border Experiences in Europe
}

\author{
Emmanuel Brunet-Jailly *
}

\author{
Border Experiences in Europe: \\ Everyday Life - Working Life - \\ Communication - Languages
}

Edited by Christian Wille \& Birte Nienaber

261 pages

Open Access (BY-NC-ND)

Nomos, 2020

https://doi.org/10.5771/9783845295671

This edited volume on life in borderlands consists of ten chapters organised in two parts: the first six chapters concern everyday life and work of borderlanders; the next four chapters explore communication and languages across borderlands.

The first part of the book is about living and speaking in borderlands. In other words, it contributes to a relatively recent trend in the field of cultural geography whereby the focus is on individuals' ordinary everyday lives and familiar experiences of the border and borderlands. This focus on the everyday evokes at some level the work of prominent writers such as Alice Munro, Carol Shield, and Rachel Cusk, who explore the lives of women in patriarchy. These eminent writers have been inspired by everyday lives, yet often excruciatingly difficult, of women in the last part of last century, a period of supposed 'liberation'. What is praise-worthy in this volume is that Wille and Nienaber also focus on the ordinary lives of everyday individuals in contemporary borderlands through themes that are also found in the literary world such as what is 'done somewhere by

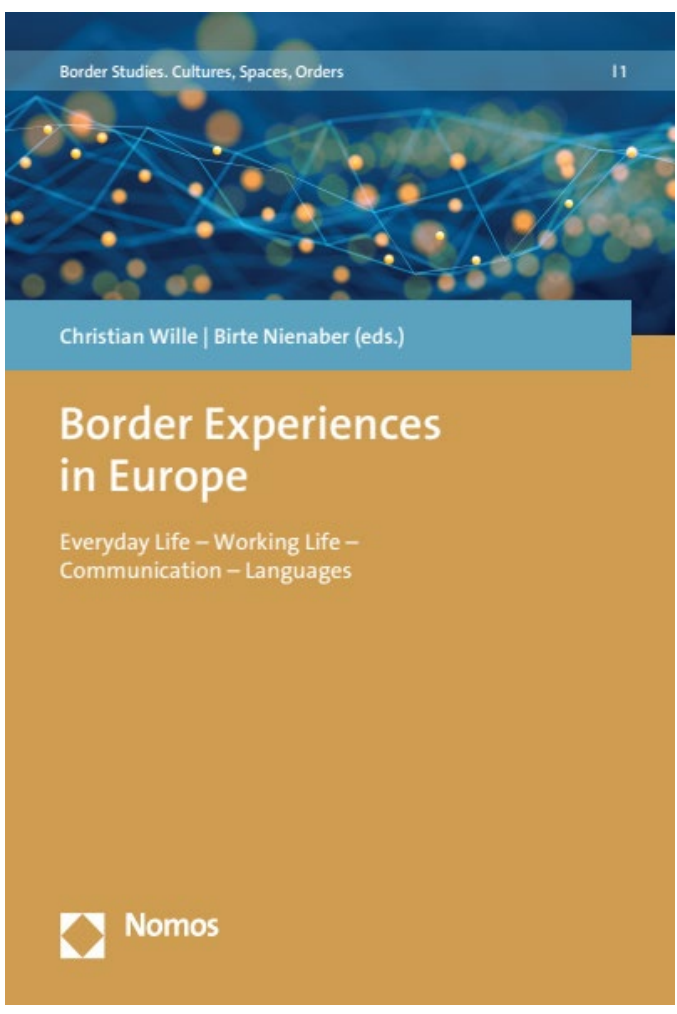

someone against some others' (Tyerman 2019, p.2) or the 'everyday cultural realities' (p.7), and 'the everyday realities of life'.

Clearly Wille and Nienaber ground their work in the research of colleagues such as Brambilla (2015) on 'humanizing the border' or Rumford 'seeing like a border' (2012), and prominently by Considère and Perrin (2017) on 'perceptions, [and] everyday practices ...'

* Emmanuel Brunet-Jailly, PhD, is Chief Editor of Borders in Globalization Review and Professor of Public Administration at the University of Victoria, Canada. Email: ebrunetj@uvic.ca Twitter: @ebrunetj 
thus exploring multiple positionalities either gendered, ethnic, or of relative power, marginalised or privileged, that lead to different emotions, experiences, meanings, memories of the borderlands. Ultimately questioning whether borders 'acquire existences through border experiences or become (are made)' (p.11). Thus, the editors raise three questions: (1) are borders produced through practices, discourses or objects? (2) what social logics lead such processes, and (3) which (dis) continuities emerge from the border?

Each one of the ten chapters addresses in part those subtle questions: in Chapter One Carsten Yndigegn brilliantly suggests that in the European Union nationalism and populism trends are variations of persistent national rights regimes that prevent 'the idea of a European identity [being] a reliable alternative' (p.31), an idea he anchors in Kant's and Khan's (2014) suggestion that cosmopolitan law should extend citizens' rights to non-citizens.

In Chapter Two, Ignacy Jozwiak, offers an ethnography of borderlanders' lives spanning the boundary lines of Transcarpathia in south-east Ukraine, nudged against Poland in the North, and Slovakia, Hungary and Romania. The author details how the border never seems to be experienced the same way by two individuals, and the multiple ways individuals cross the line: to give a phone-call, to learn from and watch news, acquire citizenship or register a car, always across the boundary line in one of the four contiguous countries, and in doing so are stitching lives spanning the boundary line itself; each experience being unique each time, and thus puncturing, subverting the border, forming 'gaps in Fortress Europe' or a 'blurred boundary' (p.57).

In Chapter Three, Ariela House takes the reader back to the oldest boundary line of Europe, that of France and Spain in the 1960s and 70s, a period of hardening of the border coinciding with when passports became required again by Spain (in 1966). For European nationals, in particular the neighboring French, routine arrests were testimonies of the disarray of this region, and a long period of uncertainty. When Spain lifted the passport requirement in 1978, then all EU nationals and Spanish citizens regained the right to cross the boundary line with their identity cards only.

In Chapter Four, Isabelle Pigeron-Piroth and Rachid Belkacem explore the border as a resource for workers; unemployment on one side has demographic effects on the borderland. Their focus is on the borderline of France and Luxembourg. Nearly 90,000 French workers cross daily (p.88); and 50 to 83 percent of the population of bordering municipalities live in France and work across the line (p.90). Being employed in Luxembourg and crossing the border daily is an important economic competitive advantage. But those populations also experience differences in laws, prices, wages, and labor markets that impact the regions' economic well-being, along with 'brain drain' and ongoing regional rivalries for a limited mobile work force; hence suggesting that mobility is a resource for both individuals and territories (p.98).

Chapter Five is the English translation of a paper published in 2018, which focused on the networked social relations of cross-border workers as well, but here they are studied as either commuters or residents in Luxembourg. The detailed data set shows networks spanning the borderland, as well as a reality of bedroom communities that contribute to the fragmentation of the sub-urbanized borderlands.

Chapter Six, by Elisabeth Boesen, thanks to a series of ethnographic interviews discusses home-making in the border regions. This is an exploration of migration and memories in the process whereby 'neighborly contact and linguistic interactions' matters because it 'gives shape' to the new place of belonging of recent migrants (p.139). The findings suggest that early memories are foundational and inform the long-term.

Dominilk Gerst in Chapter Seven explores the role of border knowledge as it influences border experiences and security but also more precisely, how each understanding of what a border is influences each individual experience and sense of security. This is interesting conceptually because it expands on previous works on 'borderwork' (Rumford 2008), 'border practices' (Parker and Adler-Nissen 2014), and also 'border-textures' (Weier et al 2018). In other words, the chapter is a conceptual discussion on thinking 'of' and 'within' borders i.e. concurrently suggesting that a geopolitic of knowledge may be necessary. This is one of two chapters (Chapters One and Seven) that make the book an especially necessary read, but also a bit too ambitious. As a reader, I would have liked two additional chapters: one on the geopolitics of border knowledge and one on how knowledge and borders interact in creating-or not-a sense of security. The second idea is more fully developed thanks to a textual analysis of a conference debate: it is very interesting because it suggests with Foucault that borders create 'knowledge-related space of possibilities' (p.162).

In Chapter Eight, Corinne Martin studies the digital borders and digital media practices of French crossborder commuters. The research findings point to three categories of users: those in a 'tunne' (p.179) who border their private and working lives - they work in Luxembourg and have no social life on that side of the border nor any virtual social life there. The second group called 'ambivalent' (p.185) are mostly residents of Luxembourg, and have, in a limited way, some form of social life spanning the boundary line. The third group has no specific name; they use of the whole greater region of Luxembourg and spread their social networks largely across the Dutchy and beyond its boundary lines. In the end a very interesting study, however, limited to 20 interviews. 
Chapter Nine is about in-betweenness and questions about the emergence of a liminal space at the borderland. The core issue is whether form of in-betweenness and liminality lead to a new border. The objects of study are marketing messages and resulting perceptions of new products, and languages provide the liminality of various perceptions. The findings are fascinating: only multi-lingual individuals are able to bridge those linguistic liminal spaces; the in-betweenness and their liminal meanings. Indeed, more of this grounded research is needed. In Chapter Nine, Erika Kalocsanyiova's ethnographic work looks at forced migrants' encounters with new languages, and particularly, how languages are bordering. The Luxembourgish 'Nationality Act' has a language test which 'thickens' access to citizenship and narrows respondents' sense of belonging.

The last chapter of this book by Xose-Afonso Alvarez Perez reports on the Frontespo research program looking at the Portuguese-Spanish linguistic borderland. An extensive study of 287 informants across 64 towns on each side of the boundary. The program has detailed culture and experiences of the border-regions to suggest that cultural and linguistic porosity characterises the 'transcendable', 'permeable', and 'ambivalence' of the border-a feast. All in all, like few edited collections this book provides the reader with powerful and substantiated ideas and excellent cases studies while opening new venues in cultural border studies.

\section{Works Cited}

Brambilla, Chiara. 2015. "Exploring the Critical Potential of the Borderscapes Concept”, Geopolitics 20(1): 14-34. http:// doi.org/gc945q

Khan, Gulshan. 2014. Jurgen Habermas and the crisis of European Identity. In K.N. Demetriou (ed.) The European Union in Crisis. New York: Springer. 123-139.

Parker, Noel, and Rebecca Adler-Nissen. 2012. "Picking and Choosing the 'Sovereign' Border: A Theory of Changing State Bordering Practices", Geopolitics 17(4): 773-796. https://doi.org/10.1080/14650045.2012.660582

Rumford, C. 2012. "Towards a multiperspectival study of borders", Geopolitics 17(4): 887-902. http://doi.org/ddkj

Rumford, C. 2008. "Introduction: Citizens and Borderwork in Contemporary Europe", Space and Polity 12(1): 1-12. https://doi.org/10.1080/13562570801969333

Weier, Sebastian, Astrid M. Fellner, Joachim Frenk, Daniel Kazmaier, Eva Michely, Christoph Vatter, Romana Weiershausen, Christian Wille. 2018. "Border textures as a transdisciplinary approach to the investigation of borders". A workshop report. Berliner Debatte Initial 29(1): 73-83. http://hdl.handle.net/10993/34922

Wille, Christian, and Ursula Roos. 2018. "Grenzuberschreiten de Lebenswelten an der luxemburgischen Grenze" in Karina Pallagst, Andrea Hartz, and Beate Caesar (eds.) Border Futures - Zukenft Grenze - Avenir Frontiere. Hannover: Akademie fur Raumforschung und landeplaniong. 168-189. 